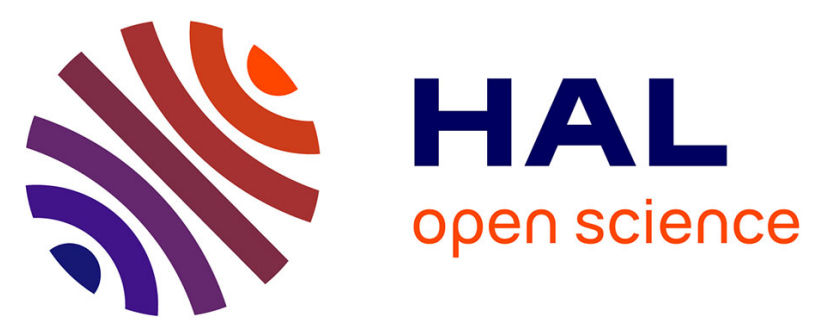

\title{
A Novel Class of PTEN Protein in Arabidopsis displays Unusual Phosphoinositide Phosphatase Activity and Efficiently Binds Phosphatidic Acid.
}

Anne Pribat, Rodnay Sormani, Mathieu Rousseau-Gueutin, Magdalena M. Julkowska, Christa Testerink, Jerome Joubes, Michel Castroviejo, Michel Laguerre, Christian Meyer, Veronique Germain, et al.

\section{To cite this version:}

Anne Pribat, Rodnay Sormani, Mathieu Rousseau-Gueutin, Magdalena M. Julkowska, Christa Testerink, et al.. A Novel Class of PTEN Protein in Arabidopsis displays Unusual Phosphoinositide Phosphatase Activity and Efficiently Binds Phosphatidic Acid.. Biochemical Journal, 2011, 441 (1), pp.161-171. 10.1042/BJ20110776 . hal-00658162

\section{HAL Id: hal-00658162 https://hal.science/hal-00658162}

Submitted on 10 Jan 2012

HAL is a multi-disciplinary open access archive for the deposit and dissemination of scientific research documents, whether they are published or not. The documents may come from teaching and research institutions in France or abroad, or from public or private research centers.
L'archive ouverte pluridisciplinaire HAL, est destinée au dépôt et à la diffusion de documents scientifiques de niveau recherche, publiés ou non, émanant des établissements d'enseignement et de recherche français ou étrangers, des laboratoires publics ou privés. 


\title{
A Novel Class of PTEN Protein in Arabidopsis displays Unusual Phosphoinositide Phosphatase Activity and Efficiently Binds Phosphatidic Acid.
}

\author{
Anne Pribat ${ }^{*}$, , Rodnay Sormani ${ }^{*} \uparrow, 1$, Mathieu Rousseau-Gueutin ${ }^{*, 3}$, Magdalena M. Julkowskat, \\ Christa Testerinkł̣, Jerôme Joubès§, Michel Castroviejo", Michel Laguerreף, Christian \\ Meyer $\dagger$, Véronique Germain ${ }^{*} \S, 2$, and Christophe Rothan*
}

${ }^{*}$ INRA, Biologie du Fruit et Pathologie, UMR 1332, Université de Bordeaux, BP 81, 33883 Villenave d'Ornon cedex, France

$\dagger$ Institut Jean-Pierre Bourgin, UMR 1318, INRA-AgroParisTech, Centre de Versailles-Grignon 78026 Versailles cedex, France

+ Section of Plant Physiology, Swammerdam Institute for Life Sciences, University of Amsterdam, Postbus 94215, NL-1090GE, Amsterdam, The Netherlands

$\S$ Laboratoire de Biogenèse Membranaire, UMR 5200, Université de Bordeaux, CNRS, 33076 Bordeaux cedex, France

II Laboratoire de Microbiologie Cellulaire et Moléculaire et Pathogénicité (UMR-CNRS 5234), Université Bordeaux Segalen, 146 rue Leo Saignat, 33076 Bordeaux cedex, France

ๆ IECB - CBMN UMR 5248 CNRS, Université de Bordeaux, 2 rue Robert Escarpit, 33607 Pessac Cedex, France

${ }^{1}$ These authors contributed equally to this work

${ }^{2}$ Correspondence should be addressed to:

Véronique Germain

Phone: +33(0)557571435

Fax: +33(0)556518361

E-mail:veronique.germain@u-bordeaux1.fr

${ }^{3}$ Present address: School of Molecular and Biomedical Science, The University of Adelaide, SouthAustralia 5005, Australia

Page Heading: A novel class of PTEN proteins in plants

Abbrevations: PA, Phosphatidic Acid; PIs, Phosphoinositides ; PI3P, Phosphatidylinositol-3 phosphate; PI4P, Phosphatidylinositol-4 phosphate; PI5P, Phosphatidylinositol-5 phosphate; $\mathrm{PI}(3,4) \mathrm{P}_{2}$, Phosphatidylinositol- $(3,4)$ bisphosphate; $\quad \mathrm{PI}(3,5) \mathrm{P}_{2}, \quad$ PhosphatidylInositol- $(3,5)$ bisphosphate; $\mathrm{PI}(3,4,5) \mathrm{P}_{3}$, PhosphatidylInositol-(3,4,5) trisphosphate; PTEN, Phosphatase and TENsin homolog deleted on chromosome ten.

Subject category: Plant 


\section{SYNOPSIS}

PTEN proteins are dual phosphatases with both protein and phosphoinositide phosphatase activity. They modulate signaling pathways controlling growth, metabolism and apoptosis in animals and are implied in several human diseases. We describe here a novel class of PTEN proteins in plants, termed PTEN2, which comprises the AtPTEN2a and AtPTEN2b proteins in Arabidopsis. Both display low in vitro tyrosine phosphatase activity. In addition, AtPTEN2a actively dephosphorylates in vitro the 3'phosphate group of $\mathrm{PI} 3 \mathrm{P}, \mathrm{PI}(3,4) \mathrm{P}_{2}$, and $\mathrm{PI}(3,5) \mathrm{P}_{2}$. In contrast to the animal PTENs, the $\mathrm{PI}(3,4,5) \mathrm{P}_{3}$ is a poor substrate. Site-directed mutagenesis of AtPTEN2a and molecular modeling of proteinphosphoinositide interactions indicated that substitutions at the PTEN2 core catalytic site of the K267 and G268 residues found in animals, and which are critical for animal PTEN activity, by the M267 and A268 residues found in the eudicot PTEN2 are responsible for changes in substrate specificity. Remarkably, the AtPTEN2a protein also displays strong binding activity for phosphatidic acid (PA), a major lipid second messenger in plants. Promoter::GUS fusion, transcript and protein analyses further showed the transcriptional regulation of the ubiquitously expressed AtPTEN2 $a$ and AtPTEN2b by salt and osmotic stress. The data suggests a function for this novel class of plant PTEN as an effector of lipid signaling in plants.

\section{KEYWORDS}

phosphoinositide phosphatase, phylogenetics, site-directed mutagenesis, phosphatidic acid binding, expression in planta 


\section{INTRODUCTION}

In eukaryotes, phosphoinositides (PIs) have emerged as second messengers in many signaling pathways, controlling important aspects of cell physiology including growth, metabolism, apoptosis, membrane dynamics, organelle identity and cytoskeletal rearrangements [1]. They are produced from the membrane lipid phosphatidylinositol and differ by the reversible phosphorylation of the inositol ring at its D3, D4 and D5 positions, giving rise to seven isomers with specific subcellular localizations and functions [2]: PI3P, PI4P, PI5P, $\mathrm{PI}(3,4) \mathrm{P}_{2}, \mathrm{PI}(3,5) \mathrm{P}_{2}, \mathrm{PI}(4,5) \mathrm{P}_{2}$ and $\mathrm{PI}(3,4,5) \mathrm{P}_{3}$. Phosphoinositide signaling events are achieved by the binding of their negatively charged headgroup to specific proteins, modifying their subcellular localization and/or their activity.

Among the plethora of phosphoinositide-metabolizing enzymes constituted by kinases, phospholipases and phosphatases, the Phosphatase and TENsin homolog deleted on chromosome 10 (PTEN) (EC 3.1.3.67) has received massive attention since its discovery in 1997 [3] for its function in human cancer (it is the most mutated gene after p53). PTEN harbors the specific catalytic motif (I/V)HCXAGXXR of protein-tyrosine phosphatases and possesses both protein and lipid phosphatase activities. PTEN tumor suppressor activity has been mainly attributed to its role as a negative regulator of the phosphatidylinositol 3-kinase (PI3K)/AKT signaling pathway $[4,5]$, which is a major growth and survival pathway in animals. In this pathway, PTEN antagonizes PI3K by removing the 3phosphate from $\mathrm{PI}(3,4,5) \mathrm{P}_{3}$ [6] which is the activator of downstream effectors like the serine/threonine kinase AKT, a proto-oncogenic protein. In addition, recent studies revealed that PTEN protein phosphatase activity or PTEN interaction with protein partners may be crucial for several physiological processes, independently from its lipid phosphatase activity [7].

In plants, a first homolog of human PTEN (HsPTEN), AtPTEN1, has been characterized in Arabidopsis thaliana [8]. Like HsPTEN, the recombinant AtPTEN1 displays in vitro $\mathrm{PI}(3,4,5) \mathrm{P}_{3}$ dephosphorylation activity. The RNAi silencing of AtPTEN1, which is specifically expressed in pollen grains, leads to pollen cell death and plant sterility. However the physiological relevance of this severe phenotype has not been established yet. It is unlikely due to $\mathrm{PI}(3,4,5) \mathrm{P}_{3}$ dephosphorylation since neither this substrate nor the class I PI3K responsible for its synthesis have been identified in plants. Though additional proteins with PTEN N-terminal phosphatase domains can be identified in plants, no characterization of their biochemical activity has been published to date. Recent advances in plant biology triggered a renewed interest for plant PTENs. First, the crucial role played by lipid signaling in plant growth and development and responses to biotic and abiotic stress is now well established [9-14]. PTEN appears as a likely effector of phospholipid signaling in plants, given its phosphoinositide phosphatase activity in animals, which targets the D3 phosphate of PI3P, PI $(3,4) \mathrm{P}_{2}$ and $\mathrm{PI}(3,4,5) \mathrm{P}_{3}$ substrates $[15,16]$. Second, additional evidence of the function of PTEN domains has been obtained in plants, with the recent implication of such a domain in the apical localization of the moss For2 formin required for rapid elongation of actin filaments [17].

Here we report the identification and characterization of new plant PTEN genes from Arabidopsis containing PTEN phosphatase and $\mathrm{C} 2$ domains, called AtPTEN2 $a$ and AtPTEN2b. We demonstrated the phospholipid activity of AtPTEN2a, which preferentially uses PI3P, in contrast to HsPTEN. We further showed that substitution of residues at the core catalytic site with those found in HsPTEN increased AtPTEN2a activity and modified its substrate specificities. Modeling of proteinphosphoinositide interactions provided likely explanations for preferential substrate use. Promoter, transcript and protein analyses further indicated that AtPTEN2 $a$ and AtPTEN2b are differentially regulated in the plant in response to environmental constraints like salinity and osmotic stress. Moreover, protein-lipid binding experiments demonstrated that AtPTEN2a effectively binds the signaling lipid phosphatidic acid (PA). Our results obtained in Arabidopsis thaliana provide new insights upon the evolution of PTEN genes from Arabidopsis and open the way for the study of their physiological function in planta.

\section{EXPERIMENTAL}

\section{Plant Materials and Growth Conditions}

Seeds from Arabidopsis thaliana (L.) Heynh. (ecotype Columbia-0) were surface-sterilized, stratified, and either plated on 0.5X Murashige and Skoog (MS) medium supplemented with $0.8 \%$ $(\mathrm{w} / \mathrm{v})$ agar and $1 \%(\mathrm{w} / \mathrm{v})$ sucrose, or placed in $0.5 \mathrm{X}$ liquid MS medium supplemented with $2 \%(\mathrm{w} / \mathrm{v})$ glucose, $20 \mathrm{mM}$ MES, pH 5.7 on a rotary shaker (120 rpm). Fifteen-day-old seedlings grown in liquid 
culture were osmotically stressed by transferring the plantlets to a new flask containing fresh medium supplemented by $0 \mathrm{mM}$ to $200 \mathrm{mM} \mathrm{NaCl}$ or Mannitol. For cultivation of adult plants, seedlings were transferred from the $0.5 \mathrm{X}$ MS solid medium to a mixture of soil-vermiculite mixture. For all experiments, the plants were cultivated at $22{ }^{\circ} \mathrm{C}$ under a daily $16 \mathrm{~h}$ light period at $150 \mu \mathrm{mol}$ of photons. $\mathrm{m}^{-2} \cdot \mathrm{s}^{-1}$.

\section{Sequence Analysis and Phylogeny}

PTEN sequences were recovered from several databases and mainly from sequenced genomes (accession numbers are given in Table S1). Accession numbers for Arabidopsis PTEN genes were At5g39400 (AtPTEN1), At3g19420 (AtPTEN2a) and At3g50110 (AtPTEN2b). Only the aminoacid sequences of the highly conserved phosphatase domain (170 to 195 aminoacids) were retained for analysis since the sequences of the $\mathrm{C} 2$ domain were too divergent. All sequences were edited and aligned manually using BioEdit [18]. The final alignment included 6 indels of 1 to 30 aminoacids that were coded as additional character states (absent: 0; present: 1), regardless of their length. They were included in subsequent sequence analyses to exploit their phylogenetic information following the procedure of Barriel [19]. Phylogenetic relationships were estimated by Maximum Parsimony (MP) and Bayesian (BML) methods. MP analysis was first conducted using PAUP * v4.0b10 [20]. The data matrix was analyzed with heuristic search and the default search options. Support of internal nodes was assessed using bootstrap analysis of 10,000 replicates. BML analysis of the same dataset was performed using the Metropolis Coupled Markov Chain Monte Carlo (MCMC) simulation program MrBayes v3.1 [21]. The indel events were included as a separate binary (restriction) data partition. Model parameters for each partition were estimated separately during the MCMC process. BML analyses were run for 5,000,000 generations and sampling every 100 generations to produce 50,000 sampled trees. Trees sampled before stationarity was reached (burnin=generation 5,000) were discarded and a $50 \%$ posterior probability bayesian consensus tree was generated from the remaining trees. The frequency of a clade in the consensus tree represents the posterior probabilities of that clade.

\section{Expression in Bacteria and Purification of Recombinant Proteins}

The Arabidopsis At3g19420 (AtPTEN2a) and At3g50110 (AtPTEN2b) genes were PCR-amplified from RAFL09-38-D10 cDNA clone (RIKEN BioResource Center, Japan) and C105193 cDNA clone (The Arabidopsis Biological Resource Center, Ohio), respectively. The primers used for amplification contained gene-specific sequences flanked by vector-specific sequences required for cloning into $\mathrm{pET}$ Ek/LIC expression vectors (Novagen, Gibbstown, NJ) (primer sequences are detailed in Table S2). The generated PCR fragments were purified, treated with T4 polymerase and ligated into pET Ek/LIC vectors following the manufacturer's protocol. The full AtPTEN2a open reading frame was cloned in pET-30 Ek/LIC to produce an in frame N-terminus His-tag fusion giving rise to pLIC30-AtPTEN2a. AtPTEN2 $b$ ORF was cloned in pET-41 Ek/LIC to produce an in frame N-terminus His and GST-tags fusion giving rise to pLIC41-AtPTEN2b. The site directed mutagenesis (pLIC-AtPTEN2aC263S and pLIC-AtPTEN2aM267K/A268G) was performed using the Quick-Change kit (Stratagene, La Jolla, $\mathrm{CA}$ ) according to the manufacturer's instructions. Pfu DNA polymerase (Stratagene) was used in all PCR reactions and all constructs were verified by sequencing. The constructs above were introduced into the BL21 (DE3) strain of Escherichia coli (Invitrogen, Carlsbad, CA) to express the corresponding recombinant proteins. Transformed cells were cultured in 0.51 of Terrific Broth medium containing $30 \mu \mathrm{g} \mathrm{ml}^{-1}$ kanamycin at $37{ }^{\circ} \mathrm{C}$. When $\mathrm{A}_{600}$ reached 0.6, isopropyl-Dthiogalactopyranoside was added to a final concentration of $1 \mathrm{mM}$ and incubation was continued for 4 $\mathrm{h}$ at $37{ }^{\circ} \mathrm{C}$. Subsequent steps were carried out at $4{ }^{\circ} \mathrm{C}$. After centrifugation, the cells were washed, resuspended in $15-\mathrm{ml}$ of lysis buffer $(50 \mathrm{mM}$ Tris-HCl, $\mathrm{pH} 7.5,1 \mathrm{mM}$ dithiothreitol [DTT], $1 \mathrm{mM}$ phenylmethanesulfonyl fluoride, $500 \mathrm{mM} \mathrm{NaCl}$ ) containing $1 \mathrm{mg} \mathrm{ml}^{-1}$ lysozyme and EDTA-free protease inhibitors (Roche Applied Science, Indianapolis, IN) and incubated at $30^{\circ} \mathrm{C}$ for $1 \mathrm{~h}$. After sonication, the soluble fraction was obtained by centrifugation $\left(20,000 \times g, 20 \mathrm{~min}\right.$ at $\left.4{ }^{\circ} \mathrm{C}\right)$. The supernatant was then loaded onto a 1-ml HisTrapTM HP column (GE Healthcare) using an Äkta Purifier (GE Healthcare). After sample loading, the column was washed with lysis buffer containing $20 \mathrm{mM}$ imidazole and the protein was eluted with the same buffer containing $250 \mathrm{mM}$ imidazole. The eluted fraction was then diluted (1/4 dilution) in $20 \mathrm{mM}$ Tris- $\mathrm{HCl}, \mathrm{pH} 7.5,1 \mathrm{mM} \mathrm{DTT}, 10 \%(\mathrm{v} / \mathrm{v})$ 
glycerol. The protein was further purified by ion exchange using a MonoQ column HR 5/5 (GE Healthcare) equilibrated with the dilution buffer describe above. The protein was eluted with a $\mathrm{NaCl}$ gradient ranging from 100 to $500 \mathrm{mM}$ over 20 column volumes. Finally, purified proteins were frozen in liquid $\mathrm{N}_{2}$ and stored at $-80{ }^{\circ} \mathrm{C}$ after adjusting the glycerol concentration up to $50 \%$.

\section{Lipid phosphatase activity using Malachite Green Assays}

PTEN hydrolyzing activity toward the different phosphoinositides was determined in vitro by the malachite green-based assay that measures the released inorganic phosphate [22]. Briefly, $2 \mu \mathrm{g}$ of recombinant protein were incubated with $100 \mu \mathrm{M}$ of one of the seven di-C8 phosphoinositide lipids (PhosphatidylInositol-3-Phosphate PI3P, PI4P, PI5P, PI(3,4) $\mathrm{P}_{2}, \mathrm{PI}(3,5) \mathrm{P}_{2}, \mathrm{PI}(4,5) \mathrm{P}_{2}$ or $\mathrm{PI}(3,4,5) \mathrm{P}_{3}$ [Echelon Biosciences, Salt Lake City, UT]) for $40 \mathrm{~min}$ (AtPTEN2a and AtPTEN2aM267K/A268G proteins) or $180 \mathrm{~min}$ (AtPTEN2b protein) at $30^{\circ} \mathrm{C}$ in a final volume of $25 \mu$. The reaction buffer was $100 \mathrm{mM}$ Tris-HCl, pH 8.0 containing $10 \mathrm{mM}$ DTT. The reaction was stopped with $100 \mu \mathrm{l}$ of malachite green reagent (Echelon Biosciences). The amount of phosphate released was determined by reading the absorbance at $660 \mathrm{~nm}$ and converted to a molar amount of product using a standard curve. The amount of protein used and the duration of the assay were within the linear range of the reaction. For the reaction with PI3P, $8 \%$ of the substrate was consumed at the end of the reaction.

\section{Molecular Modeling}

The different models of the phosphatase domain of Arabidopsis proteins have been built using the sequence alignment in Fig. S1 and the software Modeller 9 version 2 (http://salilab.org/modeller/) using the default options. In each case, 20 models were generated and the 5 lowest-energy conformers were kept for further investigation. The phosphoinositide binding assays were performed using InsightII softwares, mainly Discover and the CVFF (Constant Valence Force-Field) force-field. Point mutations were built using the Homology Module of InsightII. The general protocol used throughout is the following : the starting point is the X-ray structure of HsPTEN (code PDB: 1D5R) with $\mathrm{PI}(3,4,5) \mathrm{P}_{3}\left(\mathrm{PIP}_{3}\right)$ docked as in the paper of Lee et al. [15] by superimposing the phosphates of $\mathrm{PIP}_{3}$ on the carboxylates of tartaric acid and then deleting the latter. $\mathrm{PIP}_{3}$ was extracted from the X-ray structure of Pleckstrin homology domain of kinase B/AKT (code PDB : 1H10, name ITS). The PI3P molecule was built from $\mathrm{PIP}_{3}$, by deleting the corresponding phosphate groups. The first step is a multi-step minimization: i)- the backbone of the protein and the whole $\mathrm{PIP}_{3}$ [or the PI3P] are kept fixed and all side-chains are fully mimimized, ii)- $\mathrm{PIP}_{3}$ [or the PI3P] is then released and full minimization is resumed until the RMS is $<0.01$. Then the complex $\mathrm{PIP}_{3}$ [or the PI3P]/protein is submitted to a $100 \mathrm{ps}$ molecular dynamics run at $1000 \mathrm{~K}$ (timestep $=1 \mathrm{fs}$ ) with the protein backbone fixed. The complex is fully minimized first with the protein backbone fixed then with the protein backbone tethered with 200,100 and $50 \mathrm{kcal} / \AA 2$ constraints. Finally the complex was submitted to a $200 \mathrm{ps}$ molecular dynamics run at $500 \mathrm{~K}$ (timestep $=1 \mathrm{fs}$ ) with the protein backbone tethered with a 50 $\mathrm{kcal} / \AA 2$ constraint and 400 conformers were stored. Following a cluster graph, the two or three best solutions are submitted to full minimization and are retained for further investigation. For the plant PTEN, the starting point is obtained by superimposition of the modelled structure of the unknown PTENs on the structure of HsPTEN with $\mathrm{PIP}_{3}$ [or PI3P], then the $\mathrm{PIP}_{3}$ [or PI3P] molecule is transferred between the two proteins and HsPTEN is deleted, leaving PIP $_{3}$ [or PI3P] docked within the studied protein.

\section{Promoter activity}

The 1.16-kilobase pair (kbp) sequence of the AtPTEN2a gene promoter and the 1.27-kbp sequence of the AtPTEN $2 b$ gene promoter were amplified from genomic DNA by using specific primers (Table S2) and fused to a $\beta$-glucuronidase (GUS) reporter gene in the vector pGreenIIK-GUSORF-TerNos (http://www.pgreen.ac.uk) between Kpn I and Sal I sites. A. thaliana plants were transformed with Agrobacterium tumefaciens GV3101 carrying the constructions by using the "floral-dip" method (32). GUS activity staining was performed according to Sessions et al. [23].

\section{Western Blotting}

Plant material $(0.2 \mathrm{~g})$ was homogenized and extracted in $0.1 \mathrm{ml}$ of $50 \mathrm{mM}$ Tris-Cl, $\mathrm{pH} 8.0,1 \mathrm{mM}$ EDTA, $0.1 \%(\mathrm{w} / \mathrm{v})$ SDS, $0.1 \%(\mathrm{v} / \mathrm{v})$ triton $\mathrm{X}-100$. The extracts were cleared by centrifugation at 
$13,000 \times g$ for $15 \mathrm{~min}$ and conserved at $-80{ }^{\circ} \mathrm{C}$. SDS-PAGE and Western blot were performed using ECL western blotting Kit (GE Healthcare) according to the manufacturer protocol. The membranes were hybridized with a 1:5,000 dilution of primary antibodies. Rabbit polyclonal antibodies against peptide FASTQNDSGVENTEK for AtPTEN2a and EPPKRDDPSANRSVT peptide of AtPTEN2b were customer made by Eurogentec (France). Specificity and absence of cross-reactivity of the antibodies were further assessed by probing available pten $2 a$ and pten $2 b$ Arabidopsis insertional TDNA mutants (unpublished results).

\section{Lipid binding Assays}

For protein-lipid overlay, membrane strips pre-spotted with 100 pmol lipids (Echelon Biosciences) were first blocked with $3 \%(\mathrm{w} / \mathrm{v})$ fat free BSA in TBST $(10 \mathrm{mM}$ Tris- $\mathrm{HCl}, \mathrm{pH} 8.0 ; 150 \mathrm{mM} \mathrm{NaCl}$, $0.1 \%[\mathrm{v} / \mathrm{v}]$ Tween $_{20}$ ) and incubated with $0.5 \mu \mathrm{g} \mathrm{ml}^{-1}$ AtPTEN2a protein solution in the blocking buffer overnight at $4{ }^{\circ} \mathrm{C}$. The strips were washed with TBST and PTEN2a was subsequently revealed using immunological revelation described in the western-blotting section. To detect lipid binding in vesicles, lipid mixtures consisting of $45 \%$ phosphatidyl-choline (PC), $45 \%$ phosphoethanolamine (PE) and $10 \%$ lipid-of-interest (LOI) were used to produce vesicles sized $200 \mathrm{~nm}$ using lipid extrusion, according to Testerink et al. [24]. Dipalmitoyl PIPs were from Echelon Biosciences, all other lipids were obtained from Avanti Polar Lipids (Alabaster, USA). Two total lipid concentrations were tested, $4 \mathrm{mM}$ and $1 \mathrm{mM}$, corresponding respectively to $200 \mu \mathrm{M}$ and $50 \mu \mathrm{M}$ lipid of interest (LOI) theoretically available for binding (with headgroups facing outside of vesicle). AtPTEN2a protein $(200 \mathrm{ng})$ was added to the vesicles and incubated for $1 \mathrm{~h}$. Samples were centrifuged at $20,000 \times g$ to spin down vesicles, pellets were washed once and analysed by SDS-PAGE to detect protein bound to the vesicles. Gels were stained with colloidal Coomassie Brilliant Blue. The recombinant 2xFYVE domain tagged to GST-YFP [25] was used as a control for PI3P binding.

\section{Transcript level analysis by Real Time Quantitative PCR}

Total RNA was extracted from Arabidopsis tissues with the RNeasy plant mini kit (Qiagen, Valencia, CA). Purified RNA was treated with DNAse I using the DNA-free kit (Ambion, Austin, TX). First strand cDNA was prepared from $1 \mu \mathrm{g}$ of total RNA with the Superscript RT II kit (Invitrogen) and oligo(dT) 18 according to the manufacturer's instructions. A $0.2 \mu 1$ aliquot of the total reaction volume was used as a template in real time reverse transcription (RT)-mediated PCR amplification. The PCR amplification was performed according to Joubès et al. [26] with gene specific primers (Table S2). The relative abundance of $A C T 2$, eI $F-1 \alpha$ and $e I F-4 A-1$ in each sample was determined and used to normalize differences of total RNA amount according to the method described by Vandesompele et al. [27].

\section{RESULTS}

\section{Arabidopsis contains 3 PTEN-like genes}

PTEN proteins are characterized by two domains: a N-terminal phosphatase domain with the catalytic core signature motif of protein tyrosine phosphatases (I/V)HCXAGXXR and a C-terminal C2 domain well conserved among the metazoaires which is critical for membrane binding [28,29]. Using human PTEN (HsPTEN) and Drosophila PTEN protein as queries, we identified three PTEN homologs in the Arabidopsis genome and a higher number of proteins with PTEN domains, e.g. the For2 formin [17]. The AtPTEN1 protein has been biochemically characterized [8] whereas the two other PTEN proteins found in Arabidopsis, named AtPTEN2a and AtPTEN2b (corresponding to the At3g19420 and At3g50110 genes, respectively) have not yet been studied (Fig. 1A). AtPTEN2a and AtPTEN2b genes encode putative proteins of 611 and 632 aminoacids respectively, which are much larger than the HsPTEN and AtPTEN1 proteins (Fig. 1B). All three Arabidopsis PTEN proteins present a phosphatase domain containing the catalytic protein tyrosine phosphatases motif (InterPro 14019 , PS51181) showing $67 \%$ to $69 \%$ similarity to the human relative, and a C2 domain (InterPro 14020, PS51182). The organization of these domains is conserved between human, Drosophila and Arabidopsis.

\section{Phylogenetic analyses of PTEN}


In order to get more insights into the functional relationships of PTEN proteins in plants, we performed phylogenetic analyses of all PTEN proteins found in plants. BLAST homology search using the highly conserved phosphatase domain from HsPTEN (181 aminoacids) allowed recovery of PTEN sequences from angiosperms and gymnosperms, which were compared to lycophytes (Selaginella moellendorffii), green algae (Chlamydomonas reinhardtii) and animal PTENs (Table S1). The matrix used for phylogenetic analyses includes 182 characters, of which 30 were constant and 125 were phylogenetically informative. Parsimony analysis resulted in 96 equally most parsimonious trees of 555 steps, with a consistency index (CI) of 0.757 and a highest retention index (RI) of 0.866 . Result of phylogenetic analysis using bayesian method is shown in Fig. 2A. The strict consensus tree, which resulted in similar tree topology, is presented in Fig. S2. Within these trees, the available sequences from animals are together, while those representing various lineages of tracheophytes (including angiosperms, gymnosperms and lycophytes) are divided into two distinct and strongly supported monophyletic groups (posterior probability of 1.0 and bootstrap support of $100 \%$ ), hereafter named PTEN1 (it includes AtPTEN1) and PTEN2 (it includes AtPTEN2a and AtPTEN2b). Within the PTEN1 clade, one sequence of $S$. moellendorfii (lycophytes) is placed as sister to all available sequences from gymnosperms and part of the eudicot sequences. Within the PTEN2 clade, the other $S$. moellendorffii sequence is placed as sister to all remaining monocot and dicot sequences. The only sequence representing the green algae $(C$. reinhardtii) is more closely related to that of the PTEN2 than to that of the PTEN1 clade.

Interestingly, in comparison to the catalytic core motif HCKAGKGR found in animal PTEN, the translated sequences from the moss $S$. moellendorffii and monocots showed the typical PTEN signature i.e. C124 and R130 (HsPTEN numbering) for catalysis and the two lysine residues K125 and K128 for lipid substrate binding. Sequences from eudicots presented notable changes (Fig. 2B). For the PTEN1 clade, K125 were replaced by methionine and for the PTEN2 clade, K128 and G129 were substituted by $\mathrm{M}$ and A, respectively. Considering the crucial role played by these aminoacids in PTEN activity and substrate specificity [15], we hypothesized that such changes may alter the biochemical properties of plant PTEN2 and we therefore undertook the biochemical characterization of the eudicot PTEN2 from Arabidopsis.

\section{Purification of recombinant Arabidopsis PTEN2 proteins from E. coli}

HsPTEN has first been described as a protein tyrosine phosphatase. It was later acknowledged as a preferential lipid phosphatase using phosphatidylinositol substrates such as $\mathrm{PI}(3,4,5) \mathrm{P}_{3}[6]$. Both activities are conserved in AtPTEN1 [8]. To address the function of AtPTEN2a and AtPTEN2b, we expressed the recombinant proteins in Escherichia coli as His-tag (AtPTEN2a) or His-GST tag (AtPTEN2b) fusion proteins. Initial attempts to purify the proteins using affinity columns were largely unsuccessful because large aggregates were formed with other proteins, especially for AtPTEN2b. Affinity chromatography followed by ion exchange chromatography eventually succeeded in the purification of 6xHis-AtPTEN2a (and two mutated AtPTEN2a proteins obtained by site directed mutagenesis) and 6xHis-GST AtPTEN2b fusion proteins (Fig. 3A). SDS-PAGE analysis of the purified proteins indicated a size ca $120 \mathrm{kDa}$ for AtPTEN2a and ca $130 \mathrm{kDa}$ for AtPTEN2b proteins while the calculated mass of their translated products is $72 \mathrm{kDa}$ and $100 \mathrm{kDa}$, respectively. This was attributed to unusual gel migration patterns, possibly due to the structure of the AtPTEN2 protein domains, since mass spectrometry analysis of the purified AtPTEN2a confirmed its PTEN identity (Fig. S3).

\section{Substrate specificities of AtPTEN2 phosphatases}

Because the functional roles of PTEN are largely linked to their lipid phosphatase activity [4], we next investigated the phosphatase activity of AtPTEN2 towards various phosphoinositide substrates as described in Merlot et al. [30]. Among monophosphorylated phosphatidylinositol isomers (PIPs), the recombinant AtPTEN2a enzyme efficiently removed phosphate from the D3 position of the inositol ring, less from the D4 position and not from the D5 position (Fig. 3B). In the $\mathrm{PIP}_{2}$ isomers, the presence of a phosphate group in the D5 position led to a consistent reduction in AtPTEN2a lipid phosphatase activity. Strikingly, in contrast to animal PTEN [6] and to Arabidopsis AtPTEN1 [8], AtPTEN2a showed a very weak activity against $\mathrm{PI}(3,4,5) \mathrm{P}_{3}$ as substrate. The recombinant GST- 
AtPTEN2b protein displayed no detectable phospholipid activity, except a weak one towards PI3P. AtPTEN2b was therefore excluded from further detailed characterization.

We next analyzed the impact of mutations on those amino acids that may play a role in phosphoinositide dephosphorylation. As expected from previous studies on human PTEN [4], mutation of the catalytic C263 into S abolished AtPTEN2a activity independent of the substrate assayed (data not shown). In eudicot PTEN2, the M267 residue replaces the K found in the core catalytic site of all other PTEN proteins, including PTEN2 from monocots. The A268 residue found in AtPTEN2 proteins replaces in both eudicot and monocot PTEN2 the G found in other PTEN proteins. Both residues could be involved in the differential use of phosphoinositide substrates by AtPTEN2a in comparison with that reported for human PTEN. We therefore selected M267 and A268 for mutation, according to phylogenetic and sequence analyses previously done (Fig. 2). These mutations had a remarkable effect on AtPTEN2a phospholipid activity. The AtPTEN2a M267K/A268G protein lost its activity for PIP substrates while activity for $\mathrm{PI}(3,4) \mathrm{P}_{2}, \mathrm{PI}(3,5) \mathrm{P}_{2}$ and most notably for $\mathrm{PI}(3,4,5) \mathrm{P}_{3}$ was greatly enhanced, respectively 5-5-40 times compared to the wild type AtPTEN2a (Fig. 3C).

In addition, because animal PTENs are described as dual-specificity phosphatases (DSP) with the ability to dephosphorylate lipid substrates and also phospho-Tyr, phospho-Ser and phospho-Thr residues, we assayed AtPTEN2a Tyr phosphatase activity using para-nitrophenyl phosphate ( $p$-NPP) as a substrate [30]. The recombinant AtPTEN2a hydrolyzed poorly $p$-NPP, the affinity for this substrate being in the millimolar range $\left(\mathrm{K}_{\mathrm{m}}=8.5 \mathrm{mM}\right.$; Fig. S4). Likewise, the HsPTEN affinity for $p$ NPP is low and is in the millimolar range $(\mathrm{Km}=25.6 \mathrm{mM})[8]$.

\section{AtPTEN modelling studies of the phosphatase domain}

In order to provide additional information on the relationship between the Arabidopsis PTEN structure and function, the different models of AtPTEN1, AtPTEN2a, AtPTEN2b proteins were built using the sequence alignment in Fig. S1 as described in "Experimental" section. In each case, 20 models were generated and the 5 lowest-energy conformers were kept for further investigation. Superimposition of the three models of AtPTEN on the X-ray structure of human HsPTEN (code PDB: 1D5R) revealed weak differences in the structure of the phosphatase domain (Fig. 4A). AtPTEN2a and AtPTEN2b differ mainly from AtPTEN1 and HsPTEN by a single unstructured lipophilic loop of 8 aminoacids (Fig. 4A, Fig. S1). The two aminoacid deletion in AtPTEN1 (Fig. S1) seems to have a minimal effect on the structure of the domain. Molecular Lipophilicity Potentials (MLP) were calculated at the atomic level for HsPTEN and the 3 models of AtPTEN 1, 2a and 2b (see Supplemental "Experimental" section). From that study an increase of lipophilicity is clearly seen from AtPTEN1 (almost equivalent to HsPTEN) to AtPTEN2a and AtPTEN2b (Fig. S5). This result corroborates perfectly the difficulties encountered during purification on affinity columns as stated above.

Docking of PI $(3,4,5) \mathrm{P}_{3}$ was explored from models of HsPTEN, AtPTEN2a and the AtPTEN2a mutant M267K/A268G (Fig. 4B). The interactions observed are the following: (i) for HsPTEN : P1 with K125 and H93 - P3 with K128 and R130 - P4 with K128 and P5 with K128; (ii) for AtPTEN2a : P1 no interaction - P3 with K264 and R269 (respectively equivalent to K125 and R130 in HsPTEN) P4 with K303 and P5 with K303 (no equivalent residue for HsPTEN K128 present in this protein, as it contains M267); (iii) for the mutated version AtPTEN2a M267K/A268G : P1 with K264 and R269 (equivalent to K125 and R130 in HsPTEN) - P3 with R269 (equivalent to R130 in HsPTEN) - P4 with K303 and K267 (equivalent to HsPTEN K128) - P5 with K267 (equivalent to K128).

Even if the location is not perfectly identical, in the AtPTEN2a M267K/A268G mutant, $\mathrm{PI}(3,4,5) \mathrm{P}_{3}$ is engaged in the same interactions as in HsPTEN. On the other hand, in wildtype AtPTEN2a, the absence of $\mathrm{K}$ at position 267 leads to a reorientation of $\mathrm{PI}(3,4,5) \mathrm{P}_{3}$ and to an interaction with K303. The same experiment has been done with PI3P in AtPTEN2a and AtPTEN2a M267K/A268G models. The AtPTEN2a protein displays interactions between P1 and K264 (1 interaction) and between P3 and R269 (3) + K264 (1). The M267K/A268G AtPTEN2a mutant displays interactions between P1 and K267 (1) and between P3 and R269 (2) + K267 (1) + K264 (1). This clear result states that K267 has replaced K264 for P1 and has replaced one of the interactions with R269. Moreover (and even if there are 2 different aminoacids) the energy of the WT protein is largely lower than the mutant. The consequence of the mutation is a large displacement of PI3P 
within the active site as seen on Fig. 4C: the distance between the respective P3 is only $1.5 \AA$ but reaches $4.75 \AA$ for the respective P1 which may easily explain the absence of reactivity for the M267K/A268G mutated AtPTEN2a.

\section{AtPTEN2a affinity for phospholipid membranes in vitro}

As phosphoinositides are membrane components, we investigated the ability of AtPTEN2a to be recruited to membranes. Surprisingly, protein-lipid overlay assays with commercial pre-spotted pure lipids revealed a strong binding to phosphatidic acid (PA, Fig. 5A) whereas no binding was visible for the other lipids. In order to investigate further this binding property, AtPTEN2a was incubated with liposomes containing a mixture of phosphatidylcholine (PC), phosphatidylethanolamine (PE) and $10 \%$ of lipid of interest (LOI) :PA, phosphatidylserine (PS), PI3P, PI4P or PI5P. The SDS-PAGE analysis of AtPTEN2a bound to vesicles confirmed the result obtained by protein-lipid overlay analysis with PA at both LOI concentration (Fig. 5B) and identified a weak but clear binding for PS, even visible at $50 \mu \mathrm{M}$ LOI. No binding was obtained for liposomes containing only PC and PE or liposomes containing PC/PE and various phosphoinositides. The recombinant $2 \mathrm{XFYVE}$ domain fused to YFP-GST was used in parallel as a positive control for PI3P binding [25] and bound specifically the liposomes containing PI3P.

\section{Expression patterns of AtPTEN2 genes in planta}

To analyze the activity of AtPTEN2 promoters in planta, we produced A. thaliana plants stably transformed with AtPTEN2 $a$ and AtPTEN2 $b$ promoter::GUS transcriptional fusions. GUS staining of plant organs at several stages of development revealed that both genes were expressed in a wide range of plant organs (Fig. 6A) and that activity of the AtPTEN2a promoter was always higher. For both genes, young tissues were more intensively stained as observed in seedlings, leaves, flowers and siliques. GUS staining results were consistent with transcript accumulation patterns obtained by semiquantitative RT-PCR (Fig. S6A) and with the Genevestigator database (https://www.genevestigator.com/gv/index.jsp). The latter further indicated that AtPTEN2a transcript abundance is three to five fold higher than that of AtPTEN2b independent of the plant tissue studied (Fig. S6B). In contrast, AtPTEN1 transcript accumulation is very low except in reproductive tissues where it is restricted to pollen as previously described [8].

We next produced antibodies specific to either AtPTEN2a or AtPTEN2b isoforms and analyzed by western-blot their protein expression patterns in plant tissues (Fig. 6B). AtPTEN2a protein, like the AtPTEN2a transcript, was observed in all plant organs, but was not detectable anymore in the mature leaves or siliques. Surprisingly, given its transcript accumulation pattern, AtPTEN2b protein accumulated to higher levels in seedlings and in stem terminal nodes. Altogether, these results support a role for AtPTEN2 throughout plant development while AtPTEN1 function would be more restricted to pollen. Discrepancies between promoter activity, transcript abundance and protein levels observed in several organs or physiological stages further suggest a tight post-transcriptional regulation of both AtPTEN2 $a$ and AtPTEN2b.

Since phosphoinositide signaling is crucial for plant responses to stress $[10,13]$, we next investigated whether AtPTEN2 expression was altered in response to various stresses including dehydration, salt $(\mathrm{NaCl})$ and osmotic (mannitol) stresses. No significant changes were observed for 15-day-old plantlets submitted to $24 \mathrm{~h}$ dehydration (data not shown), while only a weak response was observed to salinity $(\mathrm{NaCl})$ stress (Fig. 7A). Conversely, osmotic stress triggered by mannitol concentrations ranging from 100 to $200 \mathrm{mM}$ considerably enhanced AtPTEN2a transcript abundance, and to a much lower level that of AtPTEN2b (Fig. 7B). This was not followed by parallel protein accumulation since AtPTEN2a and AtPTEN2b protein levels remained stable in leaves and only showed a weak increase in roots after $48 \mathrm{~h}$ exposure to mannitol at $150 \mathrm{mM}$ (Fig. 7C).

\section{DISCUSSION}

Animal PTENs are dual specificity phosphatases that can dephosphorylate both phosphotyrosine and phosphoserine/phosphothreonine residues within one substrate. In addition, animal PTENs have lipid phosphatase activity that targets the D3 phosphate from phosphoinositides. Two domains are known to play important roles in PTEN functions: the phosphatase domain and the $\mathrm{C} 2$ domain. The protein also contains a short $\mathrm{N}$-terminal $\mathrm{PI}(4,5) \mathrm{P}_{2}$ binding domain which is crucial for the binding of 
PTEN to membrane lipids [31]. We have identified in the plant model Arabidopsis three PTEN proteins displaying the canonical PTEN phosphatase domain, which includes the catalytic core signature motif of protein tyrosine phosphatases (I/V)HCXAGXXR, and the C2 domain (Fig. 1B). Phylogenetic analyses of PTEN sequences from plant and animal kingdoms suggest a duplication event of the PTEN gene early during the evolutionary history of plants. As a consequence, two distinct monophyletic groups can be clearly identified in the vascular plants (Fig. 2A). The PTEN1 clade comprises sequences from the angiosperms, gymnosperms and lycophytes. The Arabidopsis AtPTEN1 gene, which belongs to the PTEN1 clade, has been recently shown to display a PI $(3,4,5) \mathrm{P}_{3}$ dephosphorylating activity and to strongly affect pollen viability when inactivated by RNAi silencing [8]. However, neither the $\mathrm{PI}(3,4,5) \mathrm{P}_{3}$ phosphoinositide or the type I PI3K kinase which catalyzes its formation from $\mathrm{PI}(4,5) \mathrm{P}_{2}$ have ever been identified in plants, thus questioning the mode of action of PTEN1 in plants. The PTEN2 clade includes sequences from the angiosperms (eudicots and monocots) and from lycophytes. That clade is evolutionary distant from the PTEN1 clade and includes two genes in Arabidopsis: the AtPTEN2a and the AtPTEN2b genes. Like human PTEN, both AtPTEN2a and AtPTEN2b proteins are able to catalyze dephosphorylation of a synthetic protein phosphatase substrate ( $p$-NPP) and of phosphoinositides (Fig. S4 and Fig. 3), suggesting that other sequences that are present in this clade may have similar activities.

The phylogenetic pattern obtained for PTEN suggests that the duplication giving rise to the PTEN1 and the PTEN2 clades occurred at least before the divergence between lycophytes and spermaphytes (about $400 \mathrm{Mya}$ ), and most likely earlier, before the origin of the green algae. In this case, the latter would have lost the PTEN1 gene. However, further investigations in other representatives of algae would be needed to test this hypothesis. Subsequently to this duplication event, the two PTEN paralogs evolved separately. Interestingly, the duplicated genes appear to have experienced different evolutionary pathways according to the plant lineage. Lycophytes and angiosperm eudicots retained the two genes, whereas angiosperm monocots (cereals and sugarcane) seem to have lost the PTEN1 gene. The current sequencing of additional plant and eukaryote genomes will precise the origin and evolutionary dynamics of both genes in plants in the near future. In addition to the deletions observed in some lineages, subsequent duplications were observed in Arabidopsis thaliana and Populus trichocarpa by the occurrence of closely related PTEN2 sequences.

Most of the biological effects of animal PTEN are attributed to its lipid phosphatase activity that dephosphorylates the $\mathrm{PI}(3,4,5) \mathrm{P}_{3}$ and other D3 phosphate phosphoinositides [32]. Biochemical characterization of AtPTEN2 proteins shows their preferential use of 3-PIs as substrates (Fig. 3B). However, $\mathrm{PI}(3,4,5) \mathrm{P}_{3}$ was found to be a very poor substrate for the AtPTEN2s, unlike animal PTEN and Arabidopsis AtPTEN1. AtPTEN2a, which is by far the most active Arabidopsis PTEN2, dephosphorylates mostly $\mathrm{PI} 3 \mathrm{P}, \mathrm{PI}(3,4) \mathrm{P}_{2}, \mathrm{PI}(3,5) \mathrm{P}_{2}$ and also has a weak activity towards PI4P while the only AtPTEN2b substrate identified is PI3P. Detailed analysis of the aminoacid residues at the active catalytic core of plant PTENS revealed mutations at crucial positions for the PTEN1 and PTEN2 sequences (corresponding respectively to K125 in HsPTEN for PTEN1 and to K128 for PTEN2), especially in the recent eudicot lineages (Fig. 2B). In PTEN2, the absence of reactivity towards $\mathrm{PI}(3,4,5) \mathrm{P}_{3}$ and the preferential use of PI3P as substrate can be explained by amino acid changes within the PTEN domain, as shown by studies combining site-directed mutagenesis (Fig. 3C) and homology modeling of $\mathrm{PI}(3,4,5) \mathrm{P}_{3}$ and $\mathrm{PI} 3 \mathrm{P}$ docking on native and mutated AtPTEN2a protein (Fig. 4B and C). The question arises as to whether the PTEN2 lipid phosphatase activity has evolved to achieve specific functions in vascular plants, especially in eudicots, reflective of the specific diversity of phosphoinositides in plants.

All known PI isomers, with the exception of $\mathrm{PI}(3,4,5) \mathrm{P}_{3}$ and likely also $\mathrm{PI}(3,4) \mathrm{P}_{2}$, have been identified to occur in plants [13]. PI3P constitutes 5-15\% of the plant PIs and is exclusively synthesized by the type III PI3K, which is the unique type of PI3K in plants, known as Vps34. Studies of Arabidopsis type III PI3K deficient plants severely affected in both vegetative and reproductive development identified a role of PI3P in the response to salinity, as well as in endocytosis $[33,34]$. PI3P has also been found to be important for the control of stomatal movement [35]. PI(3,5) $\mathrm{P}_{2}$ was found to be increased in response to osmotic stress [36] but its role is still unknown, similar to PI5P, which is probably a degradation product of $\mathrm{PI}(3,5) \mathrm{P}_{2}$. In Arabidopsis, whereas a number of proteins called inositol polyphosphate 5- phosphatases (5PTases) are able to dephosphorylate the D5 position of the inositol ring of phosphoinositides or soluble inositol polyphosphates [37], only PTEN and 
myotubularins are potentially able to dephosphorylate D3-PIs. Like their animal counterparts, who are involved through the PI3K/AKT signaling pathway in the regulation of a wide range of processes including cell proliferation and growth, cell metabolism and apoptosis [7], the PTEN2 proteins found in vascular plant are therefore likely to play a crucial role in the control of 3-phosphorylated PI signaling events and homeostasis.

PTEN activity can be further modulated in vivo by post-translational modifications [38], interactions with protein partners [39] and localization in the nucleus or in the cytoplasm where it can shuttle between cytosol and plasma membrane [40]. Recruitment of animal PTEN to membrane requires a $\mathrm{PI}(4,5) \mathrm{P}_{2}$ binding motif and phosphorylated residues in the C-terminal domain of the protein [31] which were not identified in plant PTEN2. The phosphatase domain of AtPTEN2 proteins differs mainly from HsPTEN and AtPTEN1 by a single unstructured lipophilic loop of 8 aminoacids (Fig. 4A), with no known functional significance. However, we identified in plant PTEN2 a C2-domain, also found in animal PTEN, which may help tether PTEN to the membrane [41]. Unexpectedly, we also discovered that AtPTEN2a was able to bind phosphatidic acid (PA) and, to a lower extent, phosphatidylserine (PS) (Fig. 5A and B). Interestingly, C2 domains from other proteins have been shown to bind PA, e.g. tomato PLD $\alpha$ [42], and mammalian PKCE, which has been shown to specifically respond to PA accumulation in vivo [43]. While HsPTEN is known to bind PS [44], the binding of PA has not been reported for animal PTEN proteins. Both PS and PA are signaling lipids with various cellular and physiological effects in animals [45]. In plants, PS signaling properties have not been established yet. In contrast, PA has been implicated in a variety of processes including abiotic stress responses, pathogen defense and hormone signaling [46-47,14]. Little is known about how PA exerts its effects in plants. An increasing number of PA interacting proteins have recently been isolated in plants [47-48,9]. Among these are several protein kinases and phosphatases with roles in stress and hormonal signaling pathways such as the Raf-1 kinase homologue CTR1, involved in ethylene signaling [24], and the ABI1 phosphatase involved in abscisic acid (ABA) signaling [49]. Both act as negative regulators in their respective pathways and are inhibited by PA. Interestingly, the plant 3-phosphoinositide-dependent protein kinase-1 (PDK1), a component of the PI3K/AKT signaling pathway, which is negatively regulated by PTEN in animals, is activated by PA binding in plants [50]. In mammals, a major downstream target of this pathway, the TOR kinase is also a target of PA, which further regulates the assembly of the mTOR complexes [51]. Whether the PA binding properties of AtPTEN2a modify its activity in vivo e.g. through protein stabilization, membrane tethering, activation or inhibition of phosphatase activity, remains to be established.

In summary, our phylogenetical results strongly suggest that the PTEN gene has been duplicated in vascular plants (PTEN1 and PTEN2). When compared to human PTEN, the eudicot PTEN2 proteins display changes in charged amino acids in the core catalytic site, which likely affect their biochemical properties. As a consequence, PI3P, one of the major phosphoinositides found in plants, is the preferential substrate of the Arabidopsis AtPTEN2a protein. In contrast, the preferred substrate of HsPTEN, PI $(3,4,5) \mathrm{P}_{3}$, which has not been detected in vascular plants, is a very poor substrate for AtPTEN2a. The AtPTEN2a protein displays strong binding affinity for PA, a major lipid second messenger with roles in stress and hormonal signaling in plants. Altogether, these data suggest that the eudicot PTEN2 phosphatase has evolved to fulfill specific roles in lipid signaling. The possible regulatory role of PTEN2 in response to developmental and stress signals is consistent with the ubiquitous expression of Arabidopsis AtPTEN2 genes in the plant, especially in young organs which undergo a high metabolic activity/growth rate. In addition, strong transcriptional regulation AtPTEN2 genes in response to sait and osmotic stresses, and tight post-transcriptional regulation of AtPTEN2 protein levels are observed. Elucidating the physiological function and signaling pathways in which PTEN2 is implicated in both eudicots and monocots constitutes a new major challenge in plant science. 


\section{ACKNOWLEDGEMENTS}

We thank Dr. Teun Munnik for providing the GST-2xFYVE construct. We would like to give our thanks to the Proteomic platform from Bordeaux for the LC-MS/MS analysis of recombinant AtPTEN proteins. We also thank Dr. Sebastien Mongrand for critical reading of the manuscript.

\section{FUNDING}

This work was supported by grants from Région Aquitaine (to A.P.) and the Agence Nationale de la Recherche (ANR Blanc) (to R.S.). Work in CTs lab is funded by the Netherlands Organization for Scientific Research (NWO), grants Vidi 700.56.429, ALW 820.02.017, NGI Horizon 93511011 and STW Perspectief 10987. Also, financial support from EU-COST Action FA0605 is gratefully acknowledged.

\section{REFERENCES}

1. Martin, T. F. (1998) Phosphoinositide lipids as signaling molecules: common themes for signal transduction, cytoskeletal regulation, and membrane trafficking. Annu. Rev. Cell Dev. Biol. 14, 231-264

2. Di Paolo, G. and De Camilli, P. (2006) Phosphoinositides in cell regulation and membrane dynamics. Nature 443, 651-657

3. Li, J., Yen C., Liaw, D., Podsypanina, K., Bose, S., Wang, S. I., Puc, J., Miliaresis, C., Rodgers, L., McCombie, R., Bigner, S. H., Giovanella, B. C., Ittmann, M., and Tycko, B., Hibshoosh, H., Wigler, M. H. and Parsons R. (1997) PTEN, a Putative Protein Tyrosine Phosphatase Gene Mutated in Human Brain, Breast, and Prostate Cancer. Sciences 275, 1943-1947

4. Myers, M. P., Pass, I., Batty, I. H., Van der Kaay, J., Stolarov, J. P., Hemmings, B. A., Wigler, M. H, Downes, C. P. and Tonks, N.K. (1998) The lipid phosphatase activity of PTEN is critical for its tumor suppressor function. Proc. Natl. Acad. Sci. U.S.A. 95, 13513-13518

5. Stambolic, V., Suzuki, A., de la Pompa, J. L., Brothers, G. M., Mirtsos, C., Sasaki, T., Ruland, J., Penninger, J. M., Siderovski, D. P. and Mak, T. W. (1998) Negative Regulation of PKB/Akt-Dependent Cell Survival by the Tumor Suppressor PTEN. Cell 95, 29-39

6. Maehama, T. and Dixon, J. E. (1998) The tumor suppressor, PTEN/MMAC1, dephosphorylates the lipid second messenger, phosphatidylinositol 3,4,5-trisphosphate. J. Biol. Chem. 273, 13375-13378

7. Stiles, B. L. (2009) Phosphatase and tensin homolog deleted on chromosome 10: Extanding its PTENacles. Int. J. Biochem. Cell Biol. 41, 757-761

8. Gupta, R., Ting, J. T., Sokolov, L. N., Johnson, S. A. and Luan S. (2002) A tumor suppressor homolog, AtPTEN1, is essential for pollen development in Arabidopsis. Plant Cell 14, 2495-2507

9. Arisz, S. A., Testerink, C. and Munnik, T. (2009) Plant PA signaling via diacylglycerol kinase. Biochim. Biophys. Acta. 1791, 869-875

10. Heilmann, I. (2009) Using genetic tools to understand plant phosphoinositide. Trends Plant Sci. 14, 171-179

11. Munnik, T. and Testerink, C. (2009) Plant phospholipid signaling: 'in a nutshell'. J. Lipid Res. 50, 260-265

12. Xue, H. W., Chen, X. and Mei, Y. (2009) Function and regulation of phospholipid signalling in plants. Biochem. J. 421, 145-156

13. Munnik, T. and Vermeer, J. E. (2010) Osmotic stress-induced phosphoinositide and inositol phosphate signalling in plants. Plant Cell Environ. 33, 655-669

14. Hong, Y., Zhang, W. and Wang, X. (2010) Lipid signaling in plant response to hyperosmotic stress. Plant Cell Environ. 33, 627-635

15. Lee, J.-O., Yang, H., Georgescu, M.-M., Di Cristofano, A., Maehama, T., Shi, Y., Dixon, J. E., Pandolfi, P. and Pavletich, N. P. (1999) Crystal Structure of the PTEN tumor suppressor: Implications for its Phosphoinositide Phosphatase activity and membrane association. Cell 99, 323334 
16. Pagliarini, D. J., Worby, C. A. and Dixon, J. E. (2004) A PTEN-like phosphatase with a novel substrate specificity. J. Biol. Chem. 279, 38590-38596

17. Vidali, L., van Gisbergen, P. A., Guérin, C., Franco, P., Li, M., Burkart, G. M., Augustine, R. C., Blanchoin, L. and Bezanilla, M. (2009) Rapid formin-mediated actin-filament elongation is essential for polarized plant cell growth. Proc. Natl. Acad. Sci. U.S.A. 106, 13341-13346

18. Hall, T. A. (1999) BioEdit: a user-friendly biological sequence alignment editor and analysis program for Windows 95/98/NT. Nucl. Acids Symp. Ser. 41, 95-98

19. Barriel, V. (1994) Phylogénies moléculaires et insertions-délétions de nucléotides. In Comptes Rendus de l'Académie des Sciences, Paris. Sciences de la Vie 317, 693-701

20. Swofford, D. L. (2001). PAUP*. Phylogenetic Analysis Using Parsimony (*and Other Methods). Version 4.0. Sinauer Associates, Sunderland, Massachusetts

21. Huelsenbeck, J. P. and Ronquist, F. (2005) Bayesian analysis of molecular evolution using MrBayes. In Nielsen, R. (ed.), Statistical Methods in Molecular Evolution. Springer, New York

22. Odriozola, L., Singh, G., Hoang, T. and Chan, A. M. (2007) Regulation of PTEN activity by its carboxyl-terminal autoinhibitory domain. J. Biol. Chem. 282, 23306-23315

23. Sessions, A., Weigel, D. and Yanofsky, M. F. (1999) The Arabidopsis thaliana MERISTEM LAYER 1 promoter specifies epidermal expression in meristems and young primordial. Plant J. 20, 259-263

24. Testerink, C., Larsen, P. B., van der Does, D., van Himbergen, J. A. and Munnik, T. (2007) Phosphatidic acid binds to and inhibits the activity of Arabidopsis CTR1. J. Exp. Bot. 58, 3905-3914

25. Vermeer, J. E., van Leeuwen, W., Tobeña-Santamaria, R., Laxalt, A. M., Jones, D. R., Divecha, N., Gadella, T. W. and Munnik, T. (2006) Visualization of PtdIns3P dynamics in living plant cells. Plant J. 47, 687-700

26. Joubès, J., Raffaele, S., Bourdenx, B., Garcia, C., Laroche-Traineau, J., Moreau, P., Domergue, F. and Lessire, R. (2008) The VLCFA elongase gene family in Arabidopsis thaliana: phylogenetic analysis, 3D modelling and expression profiling. Plant Mol Biol. 67, 547-566

27. Vandesompele, J., De Preter, K., Pattyn, F., Poppe, B., Van Roy, N., De Paepe, A. and Speleman, F. (2002) Accurate normalization of real-time quantitative RT-PCR data by geometric averaging of multiple internal control genes. Genome Biol. 3, RESEARCH0034

28. Maehama, T., Taylor, G. S. and Dixon, J. E. (2001) PTEN and myotubularin: novel phosphoinositide phosphatases. Annu. Rev. Biochem. 70, 247-279

29. Das, S., Dixon, J. E. and Cho, W. (2003) Membrane-binding and activation mechanism of PTEN. Proc. Natl. Acad. Sci. U.S.A. 100, 7491-7496

30. Merlot, S., Meili, R., Pagliarini, D. J., Maehama, T., Dixon, J. E. and Firtel, R.A. (2003) A PTEN-related 5-phosphatidylinositol phosphatase localized in the Golgi. J. Biol. Chem. 278, 3986639873

31. Rahdar, M., Inoue, T., Meyer, T., Zhang, J., Vazquez, F. and Devreotes, P. N. (2009) A phosphorylation-dependent intramolecular interaction regulates the membrane association and activity of the tumor suppressor PTEN. Proc. Natl. Acad. Sci. U.S.A 106, 480-485

32. Liu, Y. and Bankaitis, V. A. (2010) Phosphoinositide phosphatases in cell biology and disease. Prog. Lipid Res. 49, 201-217

33. Lee, Y., Bak, G., Choi, Y., Chuang, W. I. and Cho, H. T. (2008) Roles of phosphatidylinositol 3-kinase in root hair growth. Plant Physiol. 147, 624-635

34. Leshem, Y., Seri, L. and Levine, A. (2007) Induction of phosphatidylinositol 3-kinasemediated endocytosis by salt stress leads to intracellular production of reactive oxygen species and salt tolerance. Plant J. 51, 185-197

35. Choi, Y., Lee, Y., Jeon, B. W., Staiger, C. J. and Lee, Y. (2008) Phosphatidylinositol 3- and 4-phosphate modulate actin filament reorganization in guard cells of day flower. Plant Cell Environ. 31, 366-377

36. Meijer, H. J. G., Divecha, N., van den Ende, H., Musgrave, A. and Munnik, T. (1999) Hyperosmotic stress induces rapid synthesis of phosphatidyl-D-inositol 3,5-bisphosphate in plant cells. Planta 208, 294-298

37. Berdy, S. E., Kudla, J., Gruissem, W. and Gillaspy, G. E. (2001) Molecular characterization of At5PTase1, an inositol phosphatase capable of terminating inositol triphosphate signaling. Plant Physiol. 126, 801-810 
38. Maccario, H., Perera, N. M., Gray, A., Downes, C. P. and Leslie, N. R. (2010) Ubiquitination of PTEN (phosphatase and tensin homolog) inhibits phosphatase activity and is enhanced by membrane targeting and hyperosmotic stress. J. Biol. Chem. 285, 12620-12628

39. Chagpar, R. B., Links, P. H., Pastor, M. C., Furber, L. A., Hawrysh, A.D., Chamberlain, M. D. and Anderson, D. H. (2010) Direct positive regulation of PTEN by the p85 subunit of phosphatidylinositol 3-kinase. Proc. Natl. Acad. Sci. U.S.A. 107, 5471-5476

40. Trotman, L. C., Wang, X., Alimonti, A., Chen, Z., Teruya-Feldstein, J., Yang, H., Pavletich, N. P., Carver, B. S., Cordon-Cardo, C., Erdjument-Bromage, H., Tempst, P., Chi, S. G., Kim, H. J., Misteli, T., Jiang, X. and Pandolfi, P. P. (2007) Ubiquitination regulates PTEN nuclear import and tumor suppression. Cell 128, 141-156

41. Zhang, D. and Aravind, L. (2010) Identification of novel families and classification of the C2 domain superfamily elucidate the origin and evolution of membrane targeting activities in eukaryotes. Gene 469, $18-30$

42. Tiwari, K. and Paliyath, G. (2011) Cloning, expression and functional characterization of the $\mathrm{C} 2$ domain from tomato phospholipase Da. Plant Physiol Biochem. 49, 18-32

43. Lopez-Andreo, J. M., Gomez-Fernandez, J. C. and Corbalan-Garcia, S. (2003) The simultaneous production of phosphatidic acid and diacylglycerol is essential for the translocation of protein kinase Cepsilon to the plasma membrane in RBL-2H3 cells. Mol. Biol. Cell 14, 4885-4895

44. Redfern, R. E., Redfern, D., Furgason, M. L., Munson, M., Ross, A. H. and Gericke, A. (2008) PTEN phosphatase selectively binds phosphoinositides and undergoes structural changes. Biochemistry 47, 2162-2171

45. Stace, C. L. and Ktistakis, N. T. (2006) Phosphatidic acid- and phosphatidylserine-binding proteins. Biochim. Biophys. Acta. 1761, 913-926

46. Testerink, C. and Munnik, T. (2005) Phosphatidic acid: a multifunctional stress signaling lipid in plants. Trends Plant Sci. 10, 368-375

47. Testerink, C. and Munnik, T. (2011) Molecular, cellular, and physiological responses to phosphatidic acid formation in plants. J. Exp. Bot. 7, 2349-2361

48. Testerink, C., Dekker, H. L., Lim, Z. Y., Johns, M. K., Holmes, A. B., Koster, C. G., Ktistakis, N. T. and Munnik, T. (2004) Isolation and identification of phosphatidic acid targets from plants. Plant J. 39, 527-536

49. Zhang, W., Qin, C., Zhao, J. and Wang, X. (2004) Phospholipase Da1-derived phosphatidic acid interacts with $\mathrm{ABI} 1$ phosphatase $2 \mathrm{C}$ and regulates abscisic acid signaling. Proc. Natl. Acad. Sci. U.S.A 101, 9508-9513

50. Anthony, R. G., Henriques, R., Helfer, A., Mészáros, T., Rios, G., Testerink, C., Munnik, T., Deák, M., Koncz, C. and Bögre, L. (2004) A protein kinase target of a PDK1 signalling pathway is involved in root hair growth in Arabidopsis. EMBO J. 23, 572-581

51. Toschi, A., Lee, E., Xu, L., Garcia, A., Gadir, N. and Foster, D. A. (2009) Regulation of mTORC1 and mTORC2 complex assembly by phosphatidic acid: competition with rapamycin. Mol Cell Biol. 29, 1411-1420

\section{FIGURE LEGENDS}

Figure 1. Representation of the PTEN genes and proteins from Arabidopsis thaliana.

(A) Organization of AtPTEN1 (At5g39400), AtPTEN2a (At3g19420) and AtPTEN2b (At3g50110). Boxes indicate exons, with black representing the coding sequence and white the untranslated regions. The translation start site (ATG) and stop codon (TGA) are indicated. Lines represent introns. (B) Schematic representation of conserved domains shared by PTEN. The gray box indicates the Phosphatase domain (InterPro14019, PS51181) and the black box the C2 domain (InterPro14020, PS51182). The position of the catalytic cystein (C) is also indicated.

Figure 2. Phylogenic analysis of phosphatase domain of PTEN.

(A) Posterior probability $(>50 \%)$ bayesian consensus tree based on the phosphatase domain of eukaryotic PTEN sequences. Tree produced from 5. $10^{6}$ generations. Posterior probabilities are indicated above the branches. Major groups belonging to the plant and animal kingdom are indicated. 
The sequence accessions are listed in supplemental Table 1. Thale cress (Arabidopsis thaliana), grape (Vitis vinifera), poplar (Populus trichocarpa), tomato (Solanum lycopersicum), cotton (Gossypium species, Gossypium raimondii), wheat (Triticum aestivum), rice (Oriza sativa), sorghum (Sorghum propinquum), sugarcane (Saccharum officinarum), white spruce (Picea glauca), pine (Pinus taeda), japanese cedar (Cryptomeria japonica), spike moss (Selaginella moellendorfii), Chlamydomonas reinhardtii, zebrafish (Danio rerio), african frog (Xenopus laevis), mouse (Mus musculus), human (Homo sapiens), worm (Caenorhabditis elegans). (B) Sequence alignment of the catalytic core for different clade representatives. The position of the aminoacids is indicated. Aminoacids involved in catalysis are indicated in bold. Gray boxes represent the main differences between the PTEN protein from animals and the PTEN2 protein from eudicots. $\bullet$ : position of the aminoacids non determined because of incomplete $\mathrm{N}$-terminal sequence.

Figure 3. Biochemical characterization of phosphoinositide phosphatase activity of recombinant AtPTEN2a and AtPTEN2b proteins.

(A) SDS-PAGE gel electrophoresis of $3 \mu \mathrm{g}$ of purified AtPTEN2a (lane 1), AtPTEN2a C263S (lane 2), AtPTEN2a M267K/A268G (lane 3) and $7 \mu \mathrm{g}$ of purified AtPTEN2b (lane 4). Staining was with Coomassie Blue. Position of molecular markers (M, kDa) are indicated. (B) Activity of recombinant AtPTEN2a and AtPTEN2b against various di-C8 phosphoinositides substrates. The activity was measured by the amount of free inorganic phosphate (Pi) released from the substrate using a malachite green assay as detailed under "Experimental" section. The absorbance at $660 \mathrm{~nm}$ was measured, and the released Pi was quantified by a standard curve in parallel in each experiment. Free Pi was measured in controls (buffer, substrate solutions and recombinant proteins alone) and subtracted for calculating AtPTEN2 activity. The AtPTEN2a C263S protein displayed no activity whatever the substrate tested, providing thus a negative control. (C) Activity of recombinant AtPTEN2a M267K/A268G against various di-C8 phosphoinositides substrates. The activity was measured as described in panel B. Reactions in panels B and C were carried out in triplicates and are presented as the mean \pm S.E. of two independent experiments.

Figure 4. Modeling of AtPTEN phosphatase domains.

(A) Superimposition of the three models of AtPTEN on the X-ray structure of Human PTEN (code PDB: 1D5R): HsPTEN is in red, AtPTEN1 is in yellow, AtPTEN2a is in orange and AtPTEN2b is in green. The white L shows the insertion of the lipophilic loop in AtPTEN2a and AtPTEN2b; the white * shows the two aminoacids deletion in AtPTEN1. (B) View of the superimposition of PI $(3,4,5) \mathrm{P} 3$ molecules docked into the different PTEN proteins: without energetic optimization (in yellow licorice for HsPTEN) as described in Lee et al., [15]; with energetic optimization for the other models (as licorices, in orange for HsPTEN, in green for AtPTEN2a and in cyan and larger for the mutated AtPTEN2a M267K/A268G, phosphor atoms being shown as red spheres). Note the striking difference in the $\mathrm{PI}(3,4,5) \mathrm{P} 3$ orientation (larger blue licorice) due to the mutations in AtPTEN2a. (C) Superimposition of AtPTEN2a and mutated AtPTEN2a M267K/A268G (not shown) as glassy blue ribbon, with docked PI3P molecules (as licorices, yellow for AtPTEN2a and green for AtPTEN2a M267K/A268G). Phosphor atoms of the two phosphates are shown as red spheres. The P1 phosphates are at the bottom and widely separated in the two proteins $(4.75 \AA)$ whereas the P3 phosphates are on top and almost superimposed (1.56 $)$.

Figure 5. Lipid binding assays of recombinant AtPTEN2a.

(A) Protein-lipid overlay assay for the detection of PTEN2a interacting lipids. Strips include 100 pmol of the following lipids : lyso-phosphatidic acid (L-PA); lyso-phosphocholine (L-PC); 
phosphatidylinositol (PI) and phosphorylated derivatives PI3P; PI4P; PI5P; PI(3,4) $\mathrm{P}_{2}$; PI(3,5) $\mathrm{P}_{2}$; $\mathrm{PI}(4,5) \mathrm{P}_{2} ; \mathrm{PI}(3,4,5) \mathrm{P}_{3}$; phosphatidylethanolamine (PE); phosphatidylserine (PS); phosphatidylcholine (PC); sphingosine-1-phosphate (S1P); phosphatidic acid (PA). After incubation of $0.5 \mu \mathrm{g} / \mathrm{ml}$ AtPTEN2a with the strips, the protein bound to the lipids was detected by immunological revelation. (B) AtPTEN2a liposome binding assays. Lipid binding specificity of AtPTEN2a was determined by using $200 \mathrm{ng}$ of AtPTEN2a recombinant protein and $200 \mathrm{~nm}$ sized vesicles containing 45\% PC, 45\% PE and 10\% Lipid Of Interest (LOI), according to "Experimental" section. After incubation of AtPTEN2a with the vesicles, those were recovered by centrifugation and protein bound analyzed by SDS-PAGE. 2XFYVE: positive control of PI3P binding.

Figure 6. Analysis of AtPTEN2a and AtPTEN2b expression in different organs during plant development.

(A) Analysis of AtPTEN2 $a$ and AtPTEN2b promoter activity in transgenic Arabidopsis plants transformed with the respective promoter fused to $\beta$-glucuronidase (GUS). GUS histochemical staining for promAtPTEN2a::GUS plants (a, b, c, g, i, k) and for promAtPTEN2b::GUS plants (d, e, f, $\mathrm{h}, \mathrm{j}, \mathrm{l})$. a, b, c: seedling establishment, respectively $24 \mathrm{~h}, 48 \mathrm{~h}$ and $96 \mathrm{~h}$ after germination; $\mathrm{g}, \mathrm{h}$ : leaf development; i,j: silique development; $\mathrm{k}, \mathrm{l}$ : flower. Bar is $0.5 \mathrm{~mm}$ for a, b, c, d, e, f; $5 \mathrm{~mm}$ for $\mathrm{g}, \mathrm{h}, \mathrm{i}, \mathrm{j}$. (B) AtPTEN2a and AtPTEN2b protein level in seedlings (7-day-old) grown in vitro on a solid medium and in different organs of the mature plant grown in soil by western-blot analysis. Twenty $\mu \mathrm{g}$ of total proteins were loaded in each lane. The control loading is tubulin (Sigma T5168).

Figure 7. Expression of AtPTEN2a and AtPTEN2b in response to Salt and Mannitol.

(A) and (B), Transcript levels of AtPTEN2 $a$ and AtPTEN2b were determined by real time RT-PCR analysis on 15-day-old seedlings submitted to different concentrations of $\mathrm{NaCl}$ (A) or Mannitol (B) during 24h. The results are presented as Relative Transcript Abundance according to "Experimental Procedures". (C) Western-blot analysis of leaves and roots from 15-day-old seedlings submitted to $150 \mathrm{mM}$ Mannitol during $0,24 \mathrm{~h}$ or $48 \mathrm{~h}$. Experiments were carried out in triplicates and are presented as the mean \pm S.D. Statistical significance was assessed by a Student's Test: *: $\mathrm{P}<0.1$; **: $\mathrm{P}<0.05$; $* * *: \mathrm{P}<0.01$. 
A AtPTEN1 (At5g39400)

AtPTEN2a (At3g19420) ATG

B
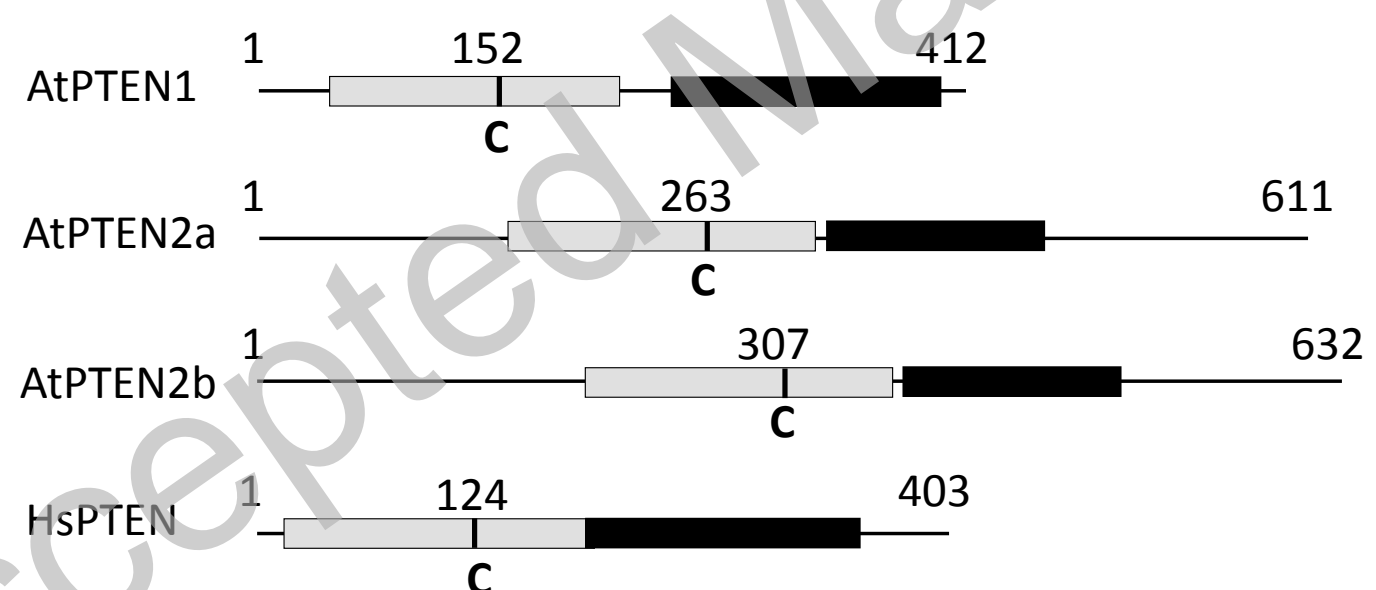

$\square$ Phosphatase domain C2 domain

\section{Fig. 1}

Licenced copy. Copying is not permitted, except with prior permission and as allowed by law. (c) 2011 The Authors Journal compilation @ 2011 Portland Press Limited 
B

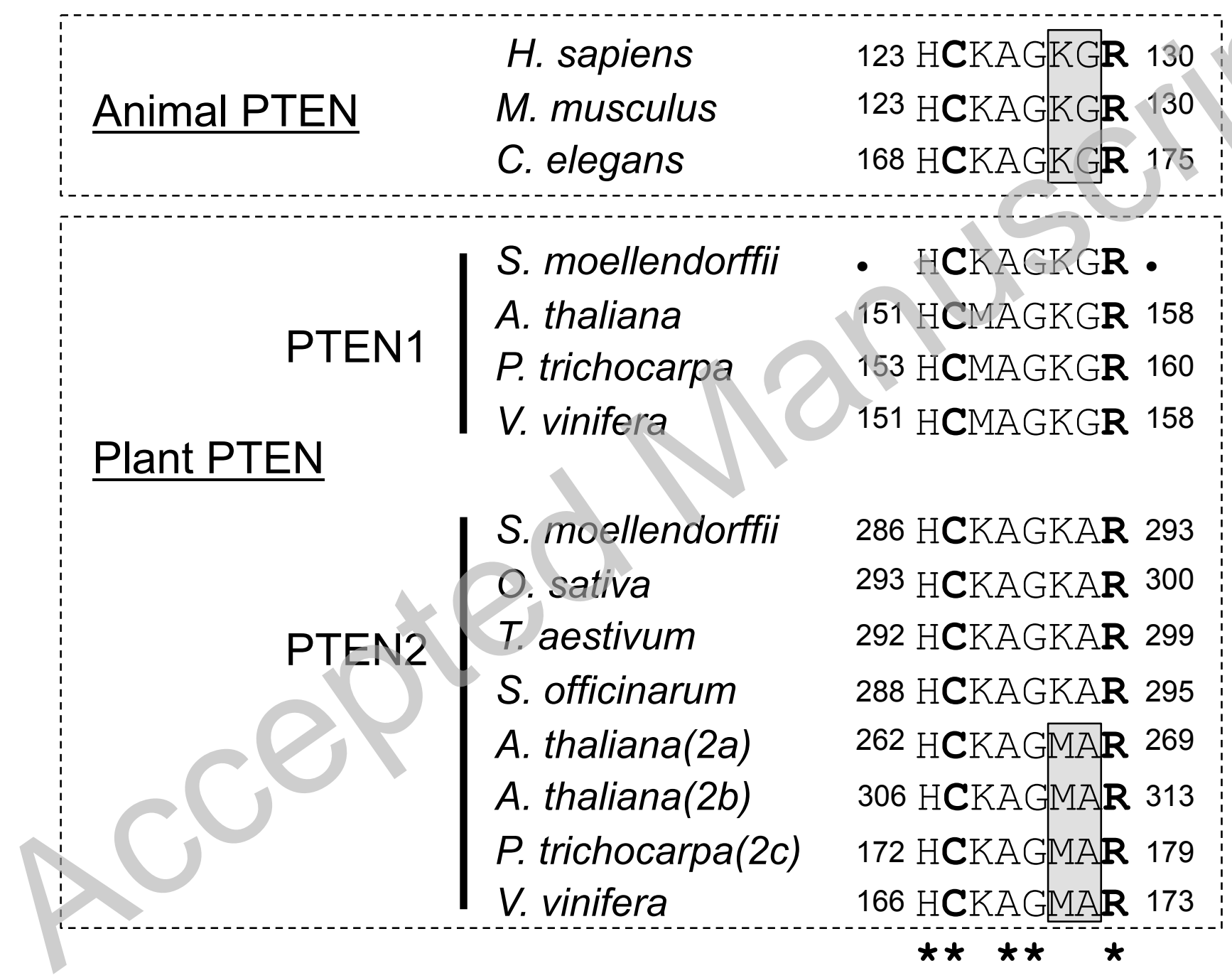

\section{Fig. 2}




\section{B] \\ Biochemical Journal Immediate Publication. Published on 24 Aug 2011 as manuscript BJ20110776}

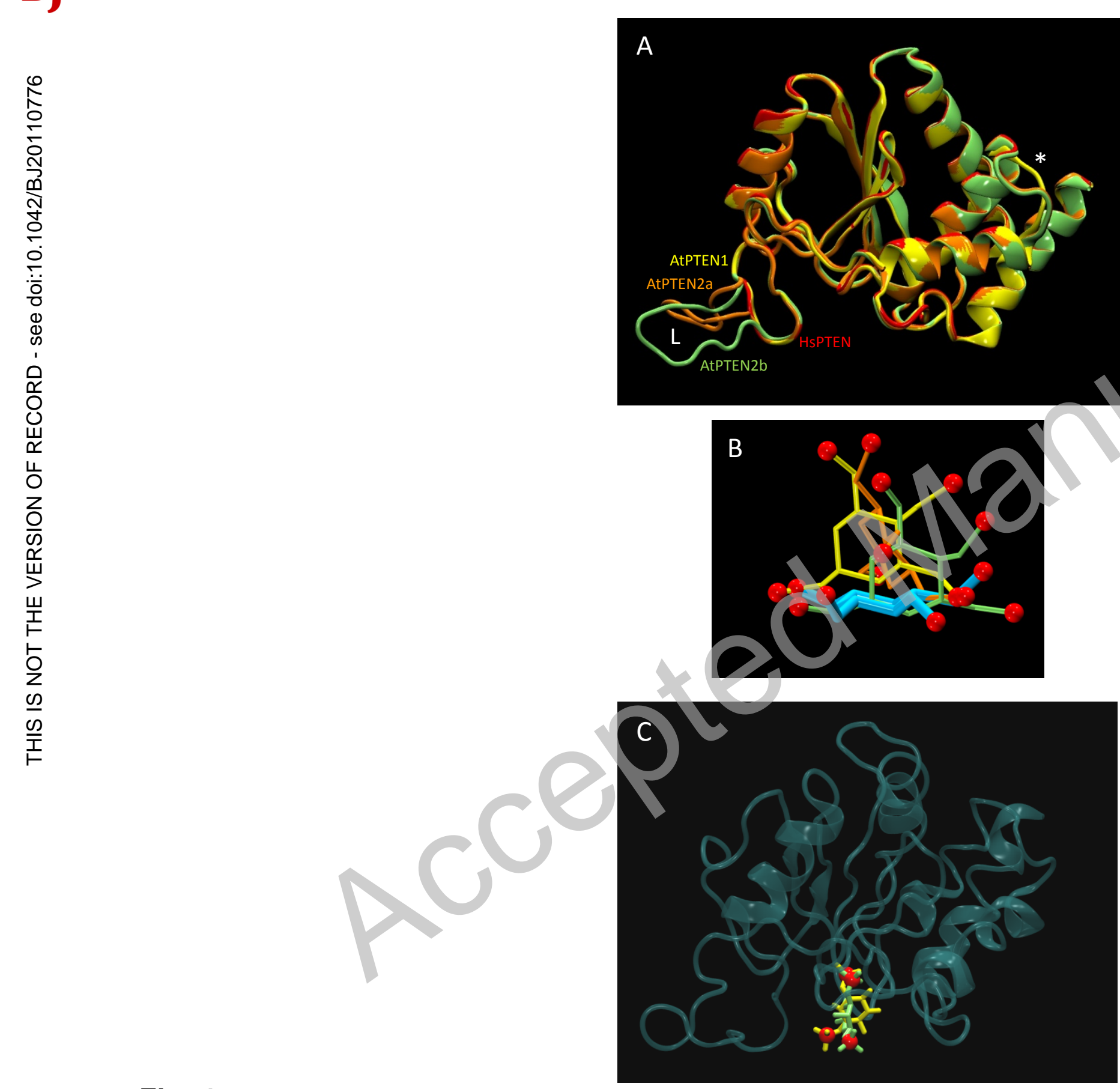

Fig. 4

Licenced copy. Copying is not permitted, except with prior permission and as allowed by law. () 2011 The Authors Journal compilation @ 2011 Portland Press Limited 


\section{B Biochemical Journal Immediate Publication. Published on 24 Aug 2011 as manuscript BJ20110776}
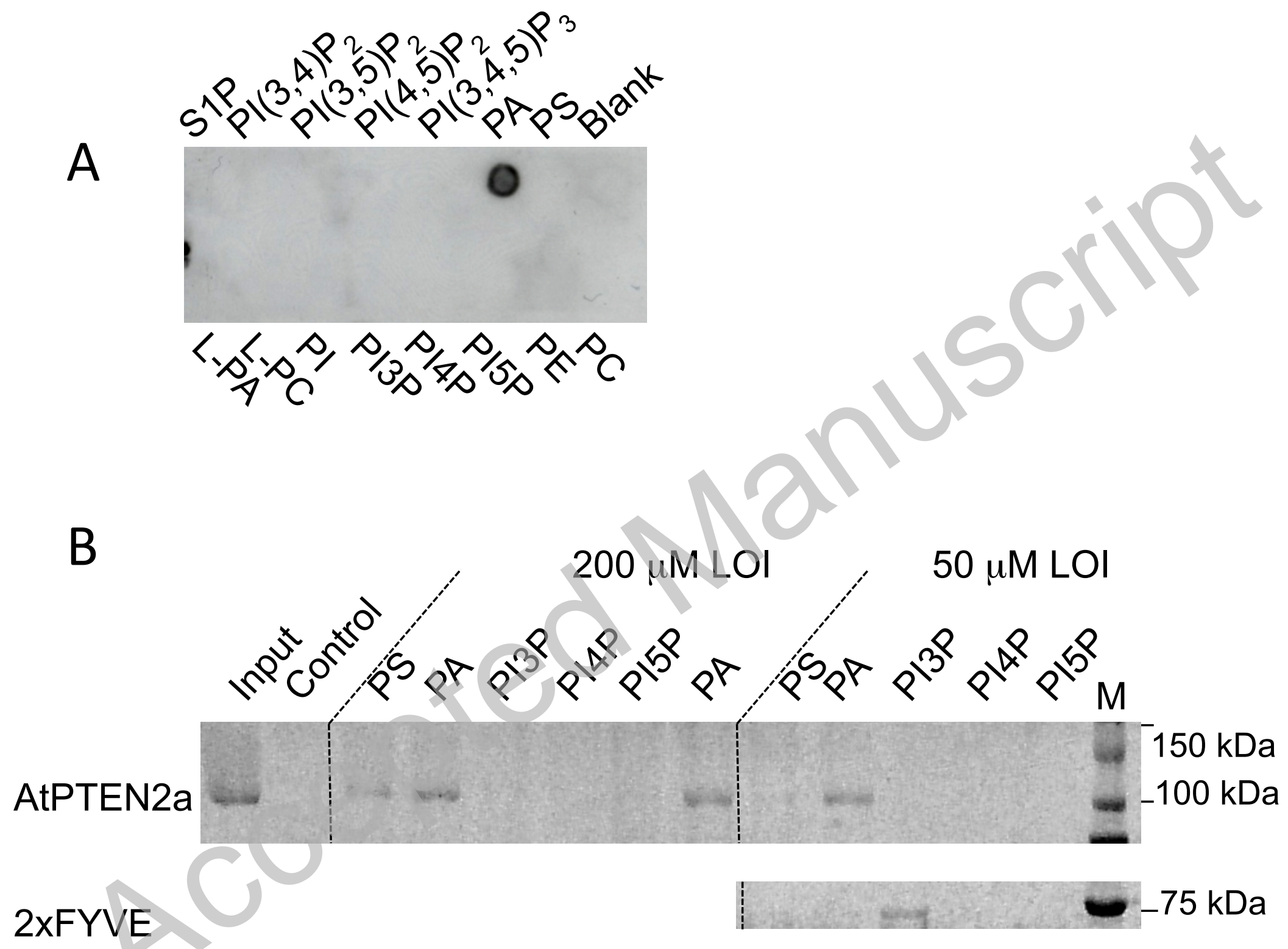

Fig. 5

Licenced copy. Copying is not permitted, except with prior permission and as allowed by law.

(C) 2011 The Authors Journal compilation ( 2011 Portland Press Limited 
B Biochemical Journal Immediate Publication. Published on 24 Aug 2011 as manuscript BJ20110776

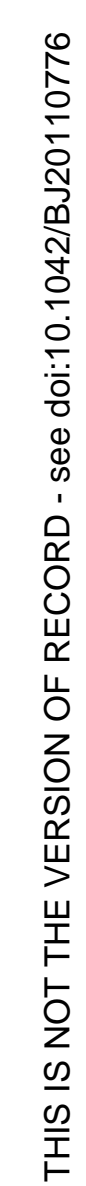

A

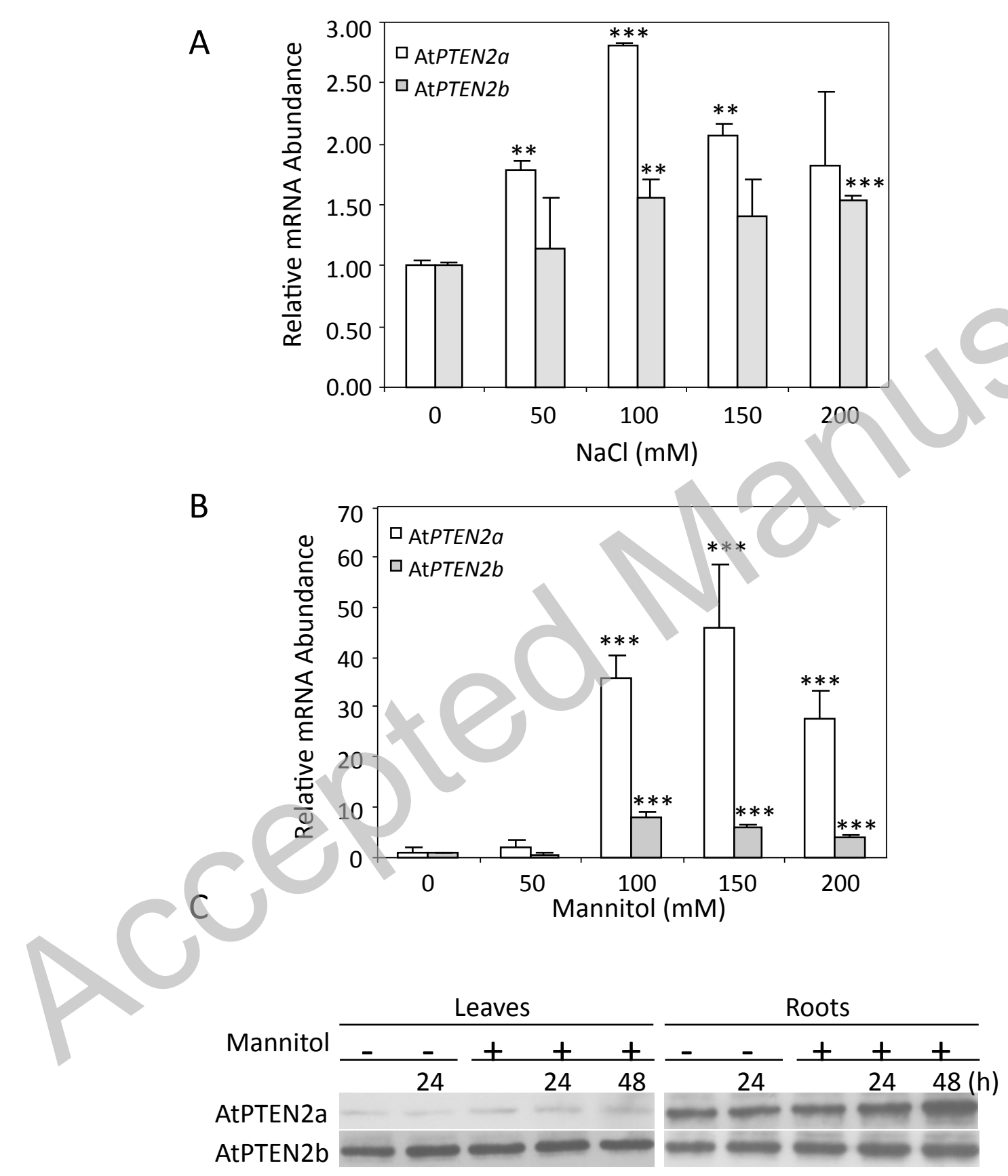

B

Fig. 7

Licenced copy. Copying is not permitted, except with prior permission and as allowed by law.

(c) 2011 The Authors Journal compilation (@ 2011 Portland Press Limited 